\title{
Disagreement in Inflation Forecasts and Inflation Risk Premia in Brazil ${ }^{*}$
}

\author{
Jonas Doi** \\ Marcelo Fernandes ${ }^{* * *}$ \\ Clemens V. A. Nunes ${ }^{* * *}$
}

\begin{abstract}
The aim of this study is to investigate the link between the inflation risk premia implied by the term structures of nominal and real interest rates in Brazil and disagreements in inflation forecasts. We gauge the former by the difference between the breakeven inflation rate and agents' inflation median expectations in the Focus Survey published by the Central Bank of Brazil. To proxy for disagreement, we employ the standard deviation of the 12-month inflation expectations in the Focus Survey. We first estimate the impact of disagreement on inflation risk premia across different horizons using a VAR approach. We find that shocks in inflation forecast disagreement significantly affect the 9-, 12-, 24- and 36-month inflation risk premia. The impact is positive, increasing with maturity at least up to 12 months. We then estimate an alternative VAR specification that summarizes the term structure of inflation risk premia by means of level, slope and curvature factors. It turns out that shocks in disagreement do not affect the slope and curvature factors, resulting only in parallel shifts in the inflation premium term structure. This is in line with the fact that the higher the dispersion in inflation expectations, the higher is the compensation that investors will require to hold fixed rate bonds.
\end{abstract}

Keywords: Break-even inflation, Risk premia, Survey expectations.

JEL Codes: E31, E43, E44.

\footnotetext{
${ }^{*}$ Submitted in November 2015. Revised in December 2016.

** Verde Asset Management S.A., Brazil. E-mail: doi.jonas@gmail.com

${ }^{* * *}$ Queen Mary, University of London and São Paulo School of Economics (EESP-FGV), Brazil. E-mail: marcelo.fernandes@fgv.br

${ }^{* * * *}$ São Paulo School of Economics (EESP-FGV), Brazil. E-mail: clemens.nunes@fgv.br
} 


\section{Introduction}

Bernanke (2007) claims that the proper management of inflation expectations is key for any stabilization policy that central bankers wish to implement. For instance, the Central Bank of Brazil has been targeting inflation since 1999 as a means to provide a nominal anchor for monetary policy and inflation expectations. However, managing inflation expectations is also about keeping dispersion in inflation expectations at bay. The goal of this paper is to examine how important the latter is. To this end, we attempt to establish how shocks in inflation forecast disagreement affect the term structure of inflation risk premia. ${ }^{1}$

Our empirical strategy rests on decomposing the breakeven inflation rate (BEIR), as measured by the difference between nominal and inflation-linked bond yields, into expected inflation and inflation risk premium. In particular, we back out the term structure of inflation risk premia by substracting survey expectations about future inflation from the breakeven inflation. This is particularly straightforward to do in Brazil because the Focus Survey from the Central Bank of Brazil is extremely informative about the cross-section of agents' macroeconomic expectations. This allows us to extract from the Focus Survey not only median inflation forecasts at different horizons, but also a neat proxy for dispersion in inflation expectations, namely, the standard deviation of the 12-month inflation forecasts.

We assess how disagreement in inflation forecasts affects the term structure of inflation risk premia using a VAR approach. In particular, we entertain two alternative specifications. The first considers a system with the inflation risk premia at different horizons $(3,6,9,12,24$ and 36 months $)$ and dispersion in inflation expectations. The second model contemplates a lower-dimensional VAR in which we summarize the term structure of inflation risk premia by means of empirical proxies for the level, slope and curvature factors. We find that, increases in the dispersion of agents' beliefs about future inflation result in a significantly positive response from longer-term inflation risk premia. Interestingly, such a shock leads mainly to parallel shifts in the term structure of inflation risk premia. We observe no significant effect on the slope and curvature factors.

The closest paper to ours is by Söderlind (2011), who finds similar evidence for the inflation risk premia in the US. As far as we know, our paper is the first to address the role of inflation forecast disagreement in Brazil. It is worth stressing, though, that there are several recent papers that use breakeven inflation rates to study inflation dynamics in Brazil. See, among others, Val et al. (2010), Weber (2011), Vicente and Guillen (2013), Caldeira and Furlani (2014), De Pooter et al. (2014), Mariani (2015), and Thiele and Fernandes (2015). The remainder of this paper is as follows. Section 2 briefly discusses some related works. Section 3

\footnotetext{
${ }^{1}$ As De Pooter et al. (2014) points out, the literature typically considers dispersion in inflation forecasts as a reasonable proxy for inflation uncertainty. However, there are some recent studies that contest such a view. See Lahiri and Sheng (2010) and Jurado et al. (2015), among others. We thank the referee for calling out our attention to this debate.
} 
describes the data as well as the empirical strategy we take. Section 4 reports the results, whereas Section 5 offers some concluding remarks.

\section{Related Works}

There is a recent growing literature that aims to assess the forecasting performance of the BEIR in Brazil. Vicente and Guillen (2013) show that it has very little predictive ability up to the 18-month horizons. For longer horizons, the situation is even worse, with a negative correlation between realized and breakeven inflation rates. Val et al. (2010) find nonetheless that the BEIR provides better forecasts than the Focus Survey from 2006 to 2008 regardless of how they extract the market-implied inflation expectations. Weber (2011) conducts a similar analysis, showing that the Top 5 inflation forecasters in the Focus Survey outperform the BEIR only up to the 6-month horizon, with the latter dominating for longer horizons. Mariani (2015) employs a Nelson-Siegel approach to estimate both the nominal and real yield curves and then assess the forecasting ability of the resulting breakeven inflation rates against the Focus Survey. He finds that they entail relatively better forecasting performance at the 6 - and 12-month horizons. In the same vein, Caldeira and Furlani (2014) estimate Svensson's (1994) model to fit the nominal and real yield curves. They show that the BEIRs predict better realized inflation than VAR models, but not as well as the Top 5 forecasters in the Focus Survey.

Rochman and Hatisuka (2011) take another route by investigating the impact of macroeconomic indicators on the anchoring of long-term inflation expectations. In particular, they estimate the long-term breakeven inflation rates using Svensson's (1994) model and then run OLS regressions to estimate their sensitivity to macroeconomic indicators. Their findings indicate that long-term expectations are steady at around $6.0 \%$ per year, well above the $4.5 \%$ target. De Pooter et al. (2014) carry out a similar analysis to assess whether inflation targeting is able to anchor long-term inflation expectations in Brazil as well as in Chile and Mexico. They show that far-forward inflation compensations in Brazil, Chile and Mexico do not significantly react to local news, though they do respond to some news in China and in the US.

Thiele and Fernandes (2015) analyze the macroeconomic determinants of the term structure of inflation expectations in Brazil. They employ Huse's (2011) yield curve model to estimate the impact of exchange rate, inflation, commodity prices and Brazil CDS on the breakeven inflation rates over different horizons. Their results evince that macroeconomic shocks affect the term structure of inflation expectations in a different manner according to the horizon. Finally, Vicente and Graminho (2014) study the liquidity and convexity effects on the inflation risk premia embedded in the Brazilian government bonds. They find that both liquidity and convexity effects are not statistically significant once one controls for expected inflation. 
As aforementioned, Söderlind (2011) is the closest paper to ours. He attempts to assess how inflation uncertainty affects the inflation risk premia. He extracts the breakeven inflation rates from the difference between fixed-rate government bond yields and the inflation-linked bond yields. Soderlind employs the average inflation forecast in the Survey of Professional Forecasters published by the Federal Reserve Bank of Philadelphia as a proxy for expected inflation and their standard deviation as a gauge of inflation uncertainty. He concludes that inflation risk premium is increasing in the dispersion of inflation forecasts, even after controlling for liquidity premium.

\section{Data Description and Methodology}

\subsection{Data}

We essentially use two databases. The first is about the agents' inflation expectations. The Central Bank of Brazil releases the Focus Survey on a weekly basis, with market participants providing forecasts for the consumer price index (IPCA) as well as for other macroeconomic indicators. Each individual forecast has a time stamp and hence we are able to compute daily expectations. There are approximately 100 participants in the survey, mostly from financial institutions and consulting firms. The Focus report pays particular attention to the sample median of inflation forecasts at different horizons. It provides not only monthly inflation forecasts from 1 to 18 months ahead, but also annual inflation rates up to 4 years ahead. In this study, we restrict attention to forecasts $n$ months ahead, with $n=3,6,9,12,24$ and 36 . Focus also discloses the daily distribution of individual forecasts for the current and next calendar year and hence we may compute the degree of disagreement in inflation expectations at the daily frequency. In particular, we gauge this dispersion by the daily standard deviation of inflation expectations over the next calendar year (see Figure 1). Unfortunately, we cannot compute this measure for horizons other than 12 months due to data limitation.

The second data set is from ANBIMA (Associação Brasileira das Entidades do Mercado Financeiro e de Capitais), gathering historical zero-coupon yields for fixed-rate and inflation-linked governments bonds. More specifically, they interpolate the fixed-rate government bond yields from LTN (Letras do Tesouro Nacional) and NTN-F (Notas do Tesouro Nacional - Série F) using a Svensson model. LTN are 6-, 12- and 24-month zero-coupon bonds, whereas NTN-F are coupon bonds with 3-, 5- and 10-year maturities. In turn, ANBIMA extracts inflation-linked yields from NTN-B (Notas do Tesouro Nacional - Série B) using once again the Svensson model. NTN-B are long-term government bonds indexed by the consumer price index (IPCA), with maturities ranging from 3 to 40 years. We collect daily data from ANBIMA for the fixed-rate and inflation-linked yields for the 3-, 6-, 9-, 12-, 24- and 36-month horizons from January, 1st 2006 to July 17, 2015.

We compute the breakeven inflation rate at time $t$ for maturity $\tau$ using the 
Figure 1

Dispersion of 12-month inflation forecasts across financial analysts

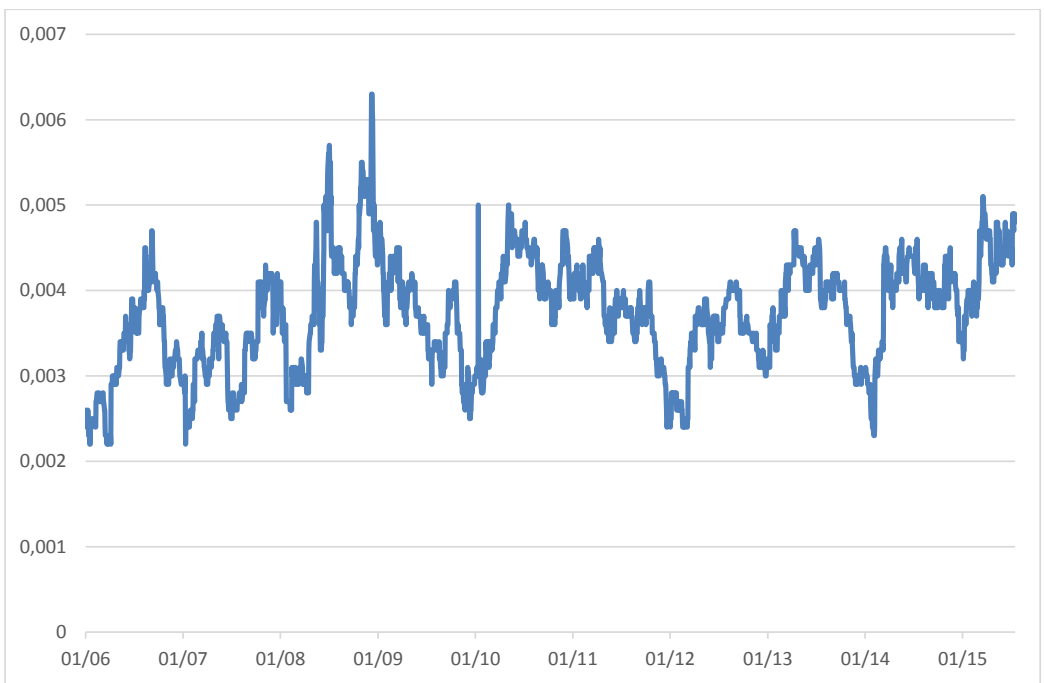

Fisher equation:

$$
B E I R_{t, t+\tau}=\frac{1+i_{t, t+\tau}}{1+\tau_{t, t+\tau}}
$$

We disregard convexity and liquidity effects on the inflation risk premia given the evidence in Vicente and Graminho (2014) and proxy expected inflation by the Focus' median inflation forecast. To compute the inflation risk premium at time $t$ for maturity $\tau$, it then suffices to substract the corresponding expected inflation from the breakeven inflation rate.

Table 1 reports some descriptive statistics for the inflation risk premia. The median inflation risk premium is positive for every maturity, ranging from $0.2 \%$ to $0.5 \%$ per year. ${ }^{2}$ The same does not apply for the average inflation risk premium, whose value is negative for the 3 -month maturity. Both average and median values seem to increase with the maturity as opposed to the standard deviation of the inflation risk premium. The high-order moments of the inflation risk premia suggest the presence of outliers at shorter horizons. The plots in Figure 2 corroborate the latter evidence. These outliers result from the extrapolation of Svensson's model

\footnotetext{
${ }^{2}$ This means that nominal bond yields move in tandem with the economy and hence investors demand an additional compensation to hold nominal assets. At shorter horizons, inflation risk premia sometimes become negative due to higher uncertainty levels in the financial markets. The historical lows in Figure 2 are exactly after the subprime and Euro crises hit the Brazilian economy, namely, between December 2008 and January 2009 and by June 2012, respectively.
} 
to the short end of the inflation-linked yield curve. Data are naturally scarce for the 3- and 6-month maturities given that the government issues NTN-Bs with maturities above 3 years.

Table 1

Descriptive statistics of the inflation risk premia

\begin{tabular}{lcccccc}
\hline & \multicolumn{7}{c}{ maturity in } & months \\
\cline { 2 - 7 } & 3 & 6 & 9 & 12 & 24 & 36 \\
\hline average & $-0.3 \%$ & $0.2 \%$ & $0.3 \%$ & $0.3 \%$ & $0.4 \%$ & $0.5 \%$ \\
median & $0.3 \%$ & $0.3 \%$ & $0.2 \%$ & $0.3 \%$ & $0.4 \%$ & $0.5 \%$ \\
minimum & $-22.6 \%$ & $-7.1 \%$ & $-2.0 \%$ & $-1.1 \%$ & $-0.7 \%$ & $-0.6 \%$ \\
maximum & $3.8 \%$ & $4.4 \%$ & $3.4 \%$ & $2.0 \%$ & $1.6 \%$ & $1.9 \%$ \\
standard deviation & $2.7 \%$ & $1.1 \%$ & $0.7 \%$ & $0.5 \%$ & $0.4 \%$ & $0.4 \%$ \\
skewness & -3.38 & -1.22 & 0.42 & -0.02 & -0.12 & 0.09 \\
excess kurtosis & 15.83 & 5.19 & 1.17 & 0.04 & -0.65 & -0.42 \\
Jarque-Bera & 20,999 & 1,078 & 405 & 875 & 1,335 & 1,172 \\
number of observations & 2,397 & 2,397 & 2,397 & 2,397 & 2,397 & 2,397 \\
\hline
\end{tabular}

Note: We gauge inflation risk premia by taking the difference between the breakeven inflation rate and agents' inflation median expectations in the Focus Survey. The sample ranges from the first week of January 2006 to the third week of July 2015. The Jarque-Bera test of normality compares sample skewness and excess kurtosis to zero. The asymptotic critical value given by a chi-squared distribution with two degrees of freedom is 9.21 at the $1 \%$ level.

We check every time series for stationarity using the augmented Dickey-Fuller test. Apart from inflation risk premia and dispersion in inflation forecasts, we also test the slope and curvature of the term structure of inflation risk premia. We proxy the former by the difference between the 24- and 6-month inflation risk premia, whereas for the latter we employ a butterfly portfolio combining the 3-, 12- and 36-month inflation risk premia. Table 2 reports the test results, which easily reject the presence of any unit root.

\subsection{Model specification}

We consider two alternative vector autoregression (VAR) specifications to evaluate the impact of inflation disagreement on inflation risk premia. The first looks at the impact of the dispersion in inflation expectations on each inflation risk premium. Apart from the standard deviation of the 12-month-ahead inflation forecasts in the Focus Survey, the system includes the inflation risk premia at the 3-, 6-, 9-, 12-, 24- and 36-month horizons. The Akaike, Hannan-Quinn and Schwartz information criteria suggest 5, 3 and 2 lags, respectively.

The second specification examines the impact of disagreement in inflation expectations on the shape of the term structure of inflation risk premia. In particular, we employ the 12-month inflation premium as a proxy for the level factor, whereas 
Figure 2

Inflation risk premia at different horizons
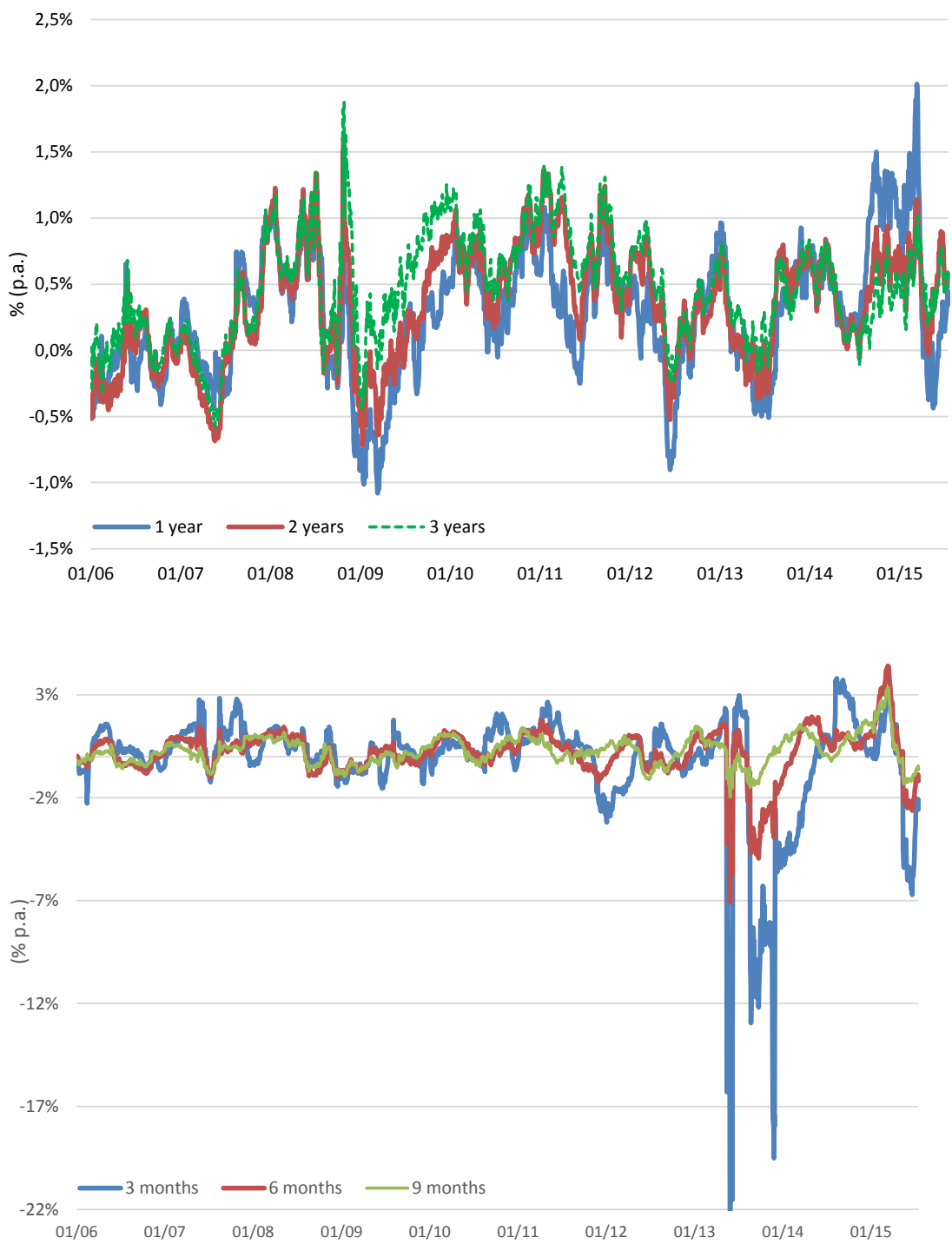
Table 2

ADF unit root tests

\begin{tabular}{lcc}
\hline Variable & $t$-stat & $p$-value \\
\hline disagreement in inflation expectations & -54.28647 & 0.0001 \\
3-month inflation risk premium & -15.17136 & 0.0000 \\
6-month inflation risk premium & -11.9352 & 0.0000 \\
9-month inflation risk premium & -14.18703 & 0.0000 \\
12-month inflation risk premium & -46.71854 & 0.0001 \\
24-month inflation risk premium & -48.69791 & 0.0001 \\
36-month inflation risk premium & -48.95382 & 0.0001 \\
slope, 24m - 6m & -12.02647 & 0.0000 \\
curvature, $(36 \mathrm{~m}-12 \mathrm{~m})-(12 \mathrm{~m}-6 \mathrm{~m})$ & -15.16689 & 0.0000 \\
\hline
\end{tabular}

Note: We gauge disagreement in inflation expectations by the standard deviation of the 12month inflation forecasts in the Focus Survey. We compute the inflation risk premia by taking the difference between the breakeven inflation rate and agents' inflation median expectations in the Focus Survey. The empirical proxies for slope and curvature of theterm structure of inflation risk premia are respectively given by the difference between the 24- and 6-month inflation risk premia and by the butterfly using the 3-, 12- and 36-month inflation risk premia. The sample ranges from the first week of January 2006 to the third week of July 2015.

we gauge slope by the difference between the 24- and 6-month inflation risk premia and curvature by a butterfly portfolio combining the 3-, 12- and 36-month inflation risk premia. The Akaike, Hannan-Quinn and Schwartz information criteria ask for 5,2 and 2 lags, respectively.

To keep both models parsimonious, we initially consider $\operatorname{VAR}(2)$ specifications and then test for residual autocorrelation. We find no evidence of residual autocorrelation up to the second order using LM tests and hence, in the next section, we treat them as congruent models to evaluate the response of the inflation risk premia to a one-standard-deviation shock in the degree of disagreement in inflation forecasts using a Cholesky decomposition. In particular, we order inflation risk premia from shorter to longer horizons in the first specification, whereas the second consider the level, slope and curvature factors in that order.

\section{Empirical Findings}

Table 3 displays the estimation results for the first specification. We find evidence of a significantly positive reaction of longer-term inflation risk premia to shocks in disagreement of beliefs about future inflation. In stark contrast, there is little action at the short end of the term structure of inflation risk premia. We deem the reasons are twofold. First, there is a scarcity of data on inflation-linked bond yields at the short term. This means that the corresponding inflation risk premia are particularly prone to measurement error due to the extrapolation of the 
short-term real interest rates by means of Svensson's model. Second, short-term inflation dynamics may indeed have a weaker response to shocks in the dispersion of longer-term inflation forecasts.

Table 3

VAR model for inflation risk premia and disagreement in inflation forecasts

\begin{tabular}{|c|c|c|c|c|c|c|c|}
\hline & \multirow[t]{2}{*}{ dispersion } & \multicolumn{6}{|c|}{ inflation risk premia } \\
\hline & & 3-month & 6 -month & 9-month & 12-month & 24-month & 36-month \\
\hline disagreement $(t-1)$ & -0.1083 & 18.539 & 0.7065 & 0.3118 & 0.2215 & 0.1759 & 0.1912 \\
\hline \multirow{2}{*}{ disagreement $(t-2)$} & $\begin{array}{l}(0.0205) \\
-0.0256\end{array}$ & $\begin{array}{c}-12.696 \\
14.932\end{array}$ & $\begin{array}{l}(0.3913) \\
0.524086\end{array}$ & $(0.1464)$ & $\begin{array}{l}(0.1086) \\
0.168729\end{array}$ & $(0.1024)$ & $\begin{array}{l}(0.1065) \\
0.192048\end{array}$ \\
\hline & $(0.0205)$ & -12.702 & $(0.39146)$ & $(0.14642)$ & $\begin{array}{l}0.168729 \\
(0.10861)\end{array}$ & $(0.1024)$ & $\begin{array}{l}0.192048 \\
(0.1065)\end{array}$ \\
\hline \multirow[t]{2}{*}{3 -month $(t-1)$} & -0.0043 & 0.0546 & 0.002953 & 0.01399 & -0.000318 & -0.00959 & -0.007396 \\
\hline & $(0.0024)$ & $(0.1482)$ & $(0.04568)$ & $(0.01709)$ & $(0.01267)$ & $(0.01195)$ & $(0.01243)$ \\
\hline 3 -month $(t-2)$ & $\begin{array}{l}0.0021 \\
(0.0024)\end{array}$ & $\begin{array}{c}0.5742 \\
(0.1479)\end{array}$ & $\begin{array}{l}0.180397 \\
(0.04559)\end{array}$ & $\begin{array}{l}0.057442 \\
(0.01705)\end{array}$ & $\begin{array}{l}0.002796 \\
(0.01265)\end{array}$ & $\begin{array}{c}-0.002266 \\
(0.01193)\end{array}$ & $\begin{array}{l}0.003838 \\
(0.0124)\end{array}$ \\
\hline \multirow[t]{2}{*}{$6-\operatorname{month}(t-1)$} & 0.0250 & -17.343 & -0.5075 & -0.2376 & -0.0346 & 0.0424 & 0.0255 \\
\hline & $(0.0133)$ & $(0.8197)$ & $(0.2526)$ & $(0.0945)$ & $(0.0701)$ & $(0.0661)$ & $(0.0687)$ \\
\hline \multirow[t]{2}{*}{$6-\operatorname{month}(t-2)$} & -0.0125 & -31.798 & -11.410 & -0.4255 & -0.0479 & 0.0143 & -0.0189 \\
\hline & $(0.0133)$ & $(0.8202)$ & $(0.2528)$ & $(0.0946)$ & $(0.0701)$ & $(0.0661)$ & $(0.0688)$ \\
\hline $9-\operatorname{month}(t-1)$ & $\begin{array}{l}-0.0533 \\
(0.0285)\end{array}$ & $\begin{array}{r}41.572 \\
-17.657\end{array}$ & $\begin{array}{l}14.642 \\
(0.5442)\end{array}$ & $\begin{array}{c}0.7202 \\
(0.2036)\end{array}$ & $\begin{array}{c}0.1446 \\
(0.1510)\end{array}$ & $\begin{array}{l}-0.0380 \\
(0.1424)\end{array}$ & $\begin{array}{l}0.0099 \\
(0.1481)\end{array}$ \\
\hline \multirow[t]{2}{*}{$9-\operatorname{month}(t-2)$} & 0.0329 & 20.288 & 12.643 & 0.8022 & 0.1611 & 0.0377 & 0.0822 \\
\hline & $(0.0286)$ & -17.673 & $(0.5447)$ & $(0.2037)$ & $(0.1511)$ & $(0.1425)$ & $(0.1482)$ \\
\hline \multirow[t]{2}{*}{$12-\operatorname{month}(t-1)$} & 0.0432 & -26.877 & -10.757 & -0.5620 & -0.1077 & 0.0015 & -0.0499 \\
\hline & $(0.0239)$ & -14.773 & $(0.4553)$ & $(0.1703)$ & $(0.1263)$ & $(0.1191)$ & $(0.1239)$ \\
\hline \multirow{2}{*}{$12-\operatorname{month}(t-2)$} & -0.0281 & 12.083 & -0.2601 & -0.5272 & -0.1527 & -0.0599 & -0.0949 \\
\hline & $(0.02$ & -14 & & $(0.1$ & $(0.1$ & $(0.1$ & $(0.1239)$ \\
\hline \multirow[t]{2}{*}{$24-\operatorname{month}(t-1)$} & -0.0124 & -0.5513 & 0.0183 & 0.1465 & 0.0784 & 0.0687 & 0.0341 \\
\hline & $(0.0161)$ & $(0.9952)$ & $(0.3067)$ & $(0.1147)$ & $(0.0851)$ & $(0.0802)$ & $(0.0834)$ \\
\hline \multirow[t]{2}{*}{$24-\operatorname{month}(t-2)$} & 0.0174 & & -0.5841 & 0.0652 & 0.0991 & 0.0466 & \\
\hline & $(0.0161)$ & $(0.9960)$ & $(0.3070)$ & $(0.1148)$ & $(0.0852)$ & $(0.0803)$ & $(0.0835)$ \\
\hline \multirow[t]{2}{*}{$36-\operatorname{month}(t-1)$} & 0.0100 & 0.4194 & 0.0361 & -0.0635 & -0.0498 & -0.0612 & -0.0165 \\
\hline & (0.0114) & $(0.7024)$ & $(0.2165)$ & $(0.0810)$ & $(0.0601)$ & $(0.0566)$ & $(0.0589)$ \\
\hline \multirow[t]{2}{*}{$36-\operatorname{month}(t-2)$} & -0.0082 & 17.36 & 0.4751 & 0.06 & -0.0042 & -0.0082 & -0.0779 \\
\hline & $(0.0114)$ & $(0.703$ & $(0.21$ & $(0.0811)$ & $(0.0602)$ & $(0.05$ & $(0.0590)$ \\
\hline \multirow[t]{2}{*}{ constant } & $1.06 \mathrm{E}-06$ & $-5.84 \mathrm{E}-06$ & $-1.55 \mathrm{E}-06$ & $7.8 \mathrm{E}-07$ & 3. $31 \mathrm{E}-06$ & $4.03 \mathrm{E}-06$ & $2.95 \mathrm{E}-06$ \\
\hline & $(2.7 \mathrm{E}-06)$ & $(0.0002)$ & $(0.0001)$ & $(1.9 \mathrm{E}-05)$ & $(1.4 \mathrm{E}-05)$ & $(1.4 \mathrm{E}-05)$ & $(1.4 \mathrm{E}-05)$ \\
\hline$R$-squared & 0.0153 & 0.0964 & 0.0992 & 0.0609 & 0.0111 & 0.0067 & 0.0055 \\
\hline
\end{tabular}

Note: Figures correspond to OLS coefficient estimates, with robust standard errors within parentheses. The sample ranges from the first week of January 2006 to the third week of July 2015.

Figure 3 plots the impulse-response functions of the inflation risk premia to a one-standard-deviation shock in the degree of disagreement using a Cholesky decomposition. In particular, we contemplate a lower triangle representation in which the dispersion in inflation forecasts affect every inflation risk premia and the inflation risk premium at a given maturity affects only the inflation risk premia of longer maturities. ${ }^{3}$ The cumulative effect is positive for all maturities, taking about 3 days to observe the maximum impact and then reaching a plateau afterwards. The disagreement effect seems to increase with maturity, flattening after 12 months. This is consistent with the fact that the higher the dispersion in inflation forecasts, the higher the compensation the investors will demand to hold fixed-rate bonds. See Söderlind (2011) for similar evidence in the US. To complement this VAR analysis, we also run Granger Causality tests. Table 4 shows

\footnotetext{
${ }^{3}$ We test this lower triangular structure using the non-Gaussian identification strategy in Lanne et al. (2016). We find no evidence against the Choleski identification at the usual confidence levels for any $t$-student distribution with up to 30 degrees of freedom. In addition, responses to Pesaran and Shin's (1998) generalized impulses that do not depend on the VAR ordering are almost identical.
} 
that we easily reject, at the usual levels of significance, the null hypothesis that disagreement in inflation expectations does not cause inflation risk premia for every maturity as from 9 months. In contrast, we find little evidence for causality running from dispersion in inflation forecasts to inflation risk premia at the 3 -and 6-month horizons.

Figure 3

Response of each inflation risk premium to a one-standard deviation shock in the degree of disagreement in inflation expectations
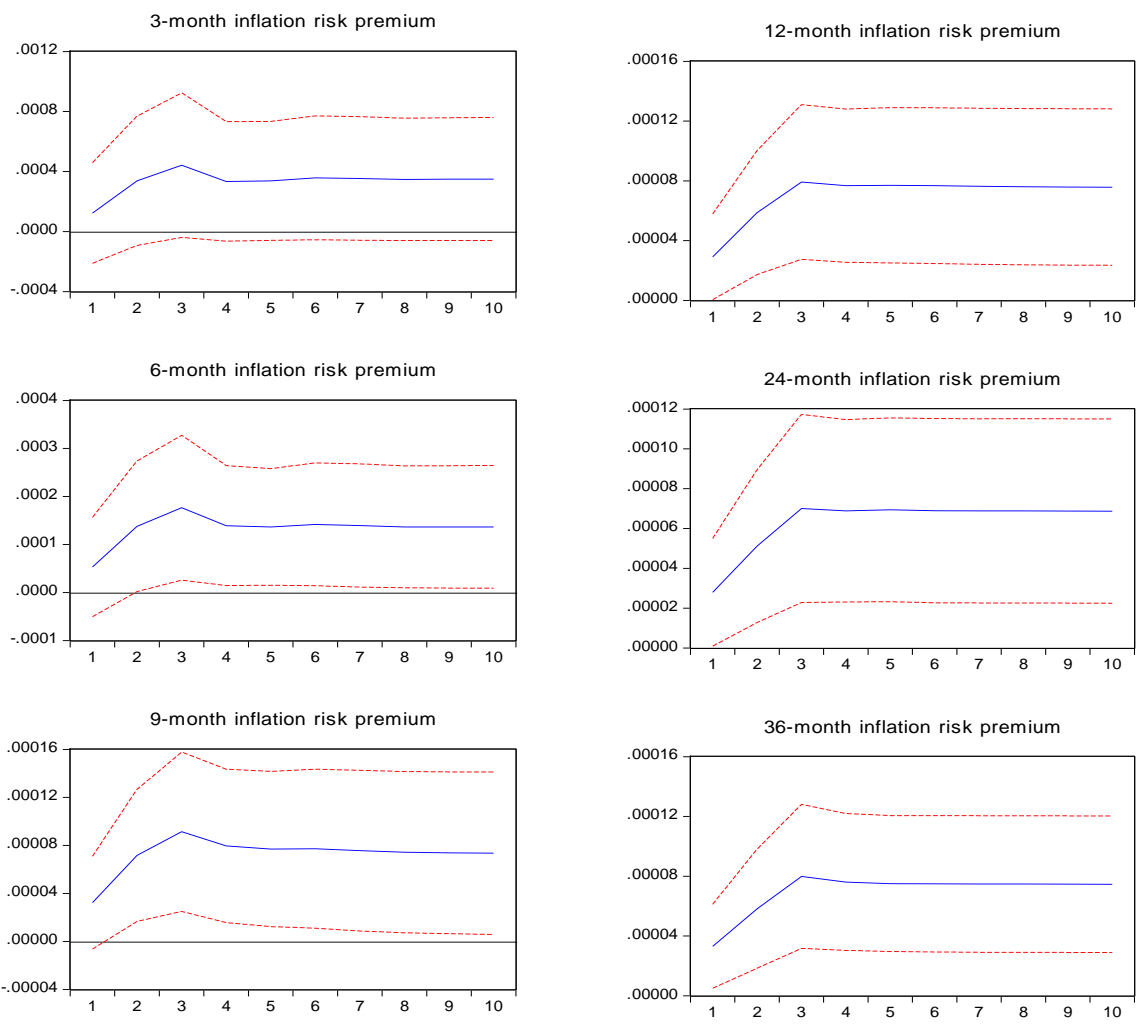

Table 5 reports the estimation results for the lower-dimensional VAR model linking disagreement in inflation expectations to the shape of the inflation risk premium term structure. We find no evidence that disagreement affects the slope and curvature factors, entailing exclusively a level effect. Figure 4 depicts the impulse-response functions of the12-month inflation risk premia, slope and curvature to a one-standard-deviation shock in the dispersion in inflation forecasts. The plots confirm little imprint in the slope and curvature proxies, but recover 
Table 4

Granger causality test from disagreement to inflation risk premia

\begin{tabular}{lrr}
\hline inflation risk premium & test statistic & $p$-value \\
\hline 3 months & 3.1795 & 0.204 \\
6 months & 4.5823 & 0.101 \\
9 months & 6.1152 & 0.047 \\
12 months & 5.9583 & 0.051 \\
24 months & 4.6906 & 0.096 \\
36 months & 5.8430 & 0.054 \\
\hline
\end{tabular}

Note: The tests are based on bivariate autoregressive specifications with two lags. The samples range from the first week of January 2006 to the third week of July 2015.

exactly the same significantly positive level effect on the 12-month inflation risk premia as in the first VAR specification. Granger causality test results confirm that disagreement in inflation expectations affects only the 12-month inflation risk premia, without any significant impact on the slope and curvature of the inflation premium term structure. ${ }^{4}$ Altogether, we conclude that a shock in the dispersion of beliefs about future inflation provokes a parallel shift in the term structure of inflation risk premia.

One possible explanation is that financial wealth allocation in Brazil is highly concentrated on fixed income, and a substantial part on short term floating rate bonds (LFT's) and the remaining on inflation linked bonds. LFT's are highly liquid and have an attractive yield. Inflation linked bonds yields follows inflation expectations. So a shock in inflation disagreement will have a likely similar impact on these bonds, since both tend to follow inflation expectations. In developed economies, where allocation is mostly on fixed rate bonds, a slope effect is expected. The impact on monetary policy in Brazil is that monetary policy loses power since the effects of exogenous monetary shocks will be mitigated given its slower impact on consumption growth. This corroborates findings on De Pooter et al. (2014), where long-run inflation expectations in Brazil appear to have been less well anchored than in Chile and Mexico. The fiscal impact is related to the fact that government debt financing will be mostly concentrated on the issue of short term floating bonds and long term inflation linked bonds, so government expenses on servicing debt will follow inflation closely.

\footnotetext{
${ }^{4}$ As before, generalized impulse responses are almost identical. We also check whether it is valid to impose a lower triangular structure using Lanne et al. (2016) approach. We are not able to reject the Choleski identification at the $5 \%$ level for any t-student distribution with over 6 degrees of freedom.
} 
Table 5

VAR model for level, slope and curvature of the inflation risk premium term structure and disagreement in inflation expectations

\begin{tabular}{lcccc}
\hline & disagreement & level & slope & curvature \\
\hline disagreement $(t-1)$ & -0.1080 & 0.2184 & -0.4830 & 1.4816 \\
& $(0.0205)$ & $(0.1085)$ & $(0.4075)$ & $(1.2891)$ \\
disagreement $(t-2)$ & -0.0248 & 0.1646 & -0.3451 & 1.2959 \\
& $(0.0205)$ & $(0.1085)$ & $(0.4078)$ & $(1.2900)$ \\
level $(t-1)$ & 0.0063 & 0.0302 & 0.1021 & -0.4799 \\
& $(0.0043)$ & $(0.0225)$ & $(0.0847)$ & $(0.2680)$ \\
level $(t-2)$ & 0.0036 & 0.0453 & 0.0424 & -0.1701 \\
& $(0.0043)$ & $(0.0225)$ & $(0.0846)$ & $(0.2676)$ \\
slope $(t-1)$ & 0.0005 & -0.0105 & 0.0793 & -0.1735 \\
& $(0.0024)$ & $(0.0125)$ & $(0.0469)$ & $(0.1484)$ \\
slope $(t-2)$ & 0.0011 & 0.0171 & -0.2289 & 0.7483 \\
curvature $(t-1)$ & $(0.0024)$ & $(0.0125)$ & $(0.0469)$ & $(0.1484)$ \\
& 0.0011 & 0.0171 & -0.2289 & 0.7483 \\
curvature $(t-2)$ & $(0.0024)$ & $(0.0125)$ & $(0.0469)$ & $(0.1484)$ \\
& $5.48 \mathrm{E}-05$ & -0.0053 & 0.0795 & -0.2412 \\
constant & $(0.0008)$ & $(0.0040)$ & $(0.0150)$ & $(0.0474)$ \\
& $1.10 \mathrm{E}-06$ & $2.63 \mathrm{E}-06$ & $1.10 \mathrm{E}-05$ & $-2.04 \mathrm{E}-05$ \\
$R$-squared & $(2.7 \mathrm{E}-06)$ & $(1.4 \mathrm{E}-05)$ & $(5.4 \mathrm{E}-05)$ & $(0.0002)$ \\
& 0.0131 & 0.0080 & 0.0830 & 0.0753 \\
\hline
\end{tabular}

Note: Figures correspond to OLS coefficient estimates, with robust standard errors within parentheses. The sample ranges from the first week of January 2006 to the third week of July 2015.

Table 6

Granger causality test from disagreement to level, slope and curvature of the inflation risk premium term structure

\begin{tabular}{lrr}
\hline factor & test statistic & $p$-value \\
\hline level & 5.7674 & 0.056 \\
slope & 1.9283 & 0.381 \\
curvature & 2.1073 & 0.349
\end{tabular}

Note: The tests are based on bivariate autoregressive specifications with two lags. The samples range from the first week of January 2006 to the third week of July 2015 
Figure 4

Response of level, slope and curvature to a one-standard-deviation shock in the degree of disagreement in inflation expectations
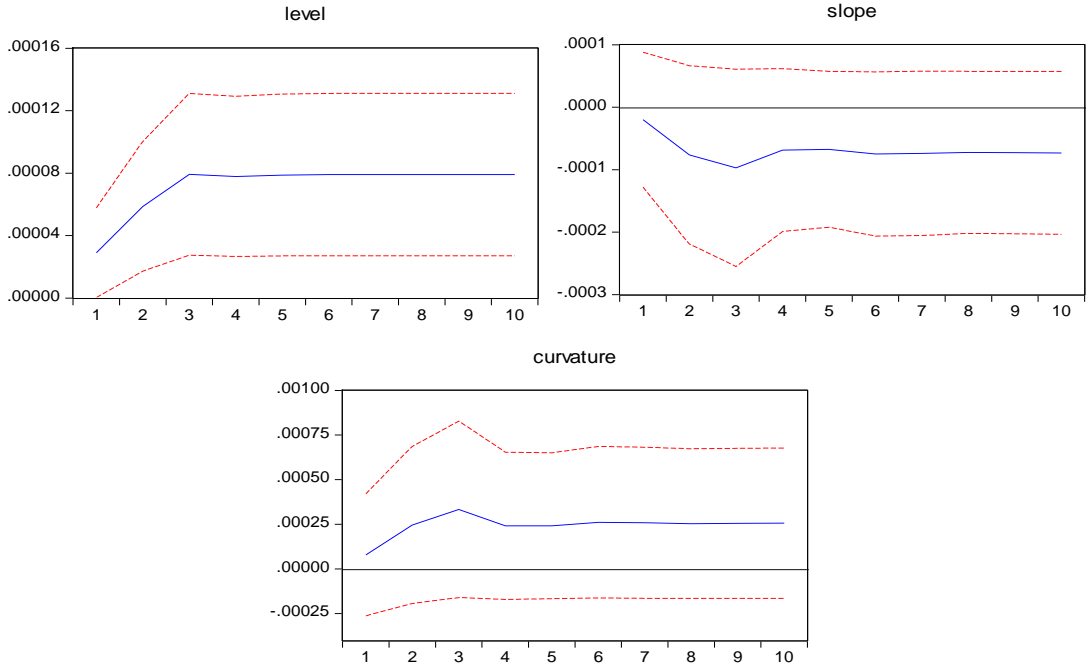

\section{Conclusions}

This paper contributes by establishing a causal link between inflation disagreement and inflation risk premia in Brazil. We first consider a system including the inflation risk premium at different horizons and inflation disagreement. We show that the latter entails a significantly positive effect on inflation risk premia at terms longer than 12 months. We then reduce the dimensionality of the VAR by focusing only on the level, slope and curvature of the term structure of the inflation risk premia in Brazil. We find that a shock in inflation disagreement seems to engender exclusively a level effect, without any impact in the slope and curvature. We deem this is a very intriguing result. Wright (2011) argues that higher inflation uncertainty should amplify the covariance between inflation and consumption growth and hence increase the term premium in nominal bonds. Given that we find no slope effect on the term structure of inflation risk premia, we conclude that the disagreement in inflation expectations affects real bonds in a similar fashion, so that inflation risk premia shift in parallel. These findings have relevant implications for monetary and fiscal policy in Brazil. 


\section{References}

Bernanke, B. (2007). Inflation expectations and inflation forecasting. In Speech delivered at the Monetary Economics Workshop of the National Bureau of Economic Research Summer Institute, Cambridge, Massachusetts.

Caldeira, J. F. \& Furlani, L. G. (2014). Inflação implícita e o prêmio pelo risco: Uma alternativa aos modelos VAR na previsão para o IPCA. Estudos Econômicos, 43:627-645.

De Pooter, M., Robitaille, P., Walker, I., \& Zdinak, M. (2014). Are long-term inflation expectations well anchored in Brazil, Chile, and Mexico? International Journal of Central Banking, 10:337-400.

Huse, C. (2011). Term structure modelling with observable state variables. Journal of Banking and Finance, 35:3240-3252.

Jurado, K., Ludvigson, S. C., \& Ng, S. (2015). Measuring uncertainty. American Economic Review, 105:1177-1216.

Lahiri, K. \& Sheng, X. (2010). Measuring forecast uncertainty by disagreement: The missing link. Journal of Applied Econometrics, 25:514-538.

Lanne, M., Meitz, M., \& Saikkonen, P. (2016). Identification and estimation of non-Gaussian structural vector autoregressions. Journal of Econometrics, 196:288-304.

Mariani, L. A. (2015). Modelos macrofinanceiros com o uso de fatores latentes do tipo Nelson-Siegel. Master's thesis, Dissertação (Mestrado em Economia Aplicada), Faculdade de Economia, Administração e Contabilidade de Ribeirão Preto, Universidade de São Paulo, Ribeirão Preto.

Pesaran, M. H. \& Shin, Y. (1998). Generalized impulse response analysis in linear multivariate models. Economics Letters, 58:17-29.

Rochman, R. R. \& Hatisuka, E. O. (2011). Títulos públicos indexados à inflação e a ancoragem das expectativas no Brasil. Master's thesis, Dissertação (Mestrado em Economia), Escola de Economia de São Paulo da Fundação Getulio Vargas.

Söderlind, P. (2011). Inflation risk premia and survey evidence on macroeconomic uncertainty. International Journal of Central Banking, 2:113-133.

Svensson, L. E. O. (1994). Estimating and interpreting forward interest rates: Sweden 1992-1994. NBER Working Paper Series 4871, National Bureau of Economic Research. 
Thiele, E. \& Fernandes, M. (2015). The macroeconomic determinants of the term structure of inflation expectations in Brazil. Brazilian Review of Econometrics, $35: 3-22$

Val, F., Barbedo, C., \& Maia, M. (2010). Expectativas inflacionárias e inflação implícita no mercado brasileiro. Technical report, Research Department of the Central Bank of Brazil.

Vicente, J. V. M. \& Graminho, F. M. (2014). Decompondo a inflação implícita. Working Paper Series 359, Central Bank of Brazil.

Vicente, J. V. M. \& Guillen, O. T. C. (2013). Do inflation-linked bonds contain information about future inflation? Revista Brasileira de Economia, 67:251-260.

Weber, M. (2011). Inflação futura: Uma análise comparativa entre as expectativas do Focus e as inflações implícitas nos títulos públicos. Master's thesis, Dissertação (Mestre em Finanças e Economia Empresarial), Escola de Economia de São Paulo da Fundação Getulio Vargas.

Wright, J. H. (2011). Term premia and inflation uncertainty: Empirical evidence from an international panel dataset. American Economic Review, 101:15141534 . 